\title{
Experimental research of vehicle traction properties for reconstruction of traffic accidents
}

\author{
Marian Dudziak ${ }^{1}$, Andrzej Lewandowski ${ }^{2}$, Michat Śledziński ${ }^{* 3}$ \\ ${ }^{1}$ The President Stanisław Wojciechowski State University of Applied Sciences in Kalisz, Nowy Świat \\ Street 4, 62-800 Kalisz, Poland \\ ${ }^{2}$ Institute of Forensic Research, Cracow, ul. Westerplatte 9, 31-033 Kraków, Poland \\ ${ }^{3}$ Chair of Basics of Machine Design, Poznan University of Technology, Poznan, 60-965, Poland
}

\begin{abstract}
In order to broaden the database of motor vehicle traction properties in unusual conditions, the research team has performed experimental studies: on wet and snow-covered surfaces. Tests of vehicles equipped with winter tyres with non-skid snow chains have been performed on snow-covered surfaces. It has been shown that on snowy surface chains affect vehicle traction properties, mostly during acceleration. They increase the rate of acceleration up to 50\% compared to a vehicle with winter tyres without chains. The results of the performed research can be the basis for the full reconstruction of road accidents under these conditions. Knowledge of traction properties of cars in difficult and unusual conditions is an important cognitive factor and serves to improve road safety.
\end{abstract}

Keywords: traffic accidents, reconstruction, snow chains, Traction Control System, the coefficient of adhesion

\section{Introduction}

Road incidents often take place under difficult conditions arising from the state of the surface (eg. wet, snowy). Reconstruction of a traffic accident [1] requires knowledge about the behaviour of a vehicle in such conditions. The most effective method of obtaining data about the vehicle's traction properties is experimental research [2] in real traffic conditions, which is what drives the authors' interest in this issue.

In snowy driving conditions, traction characteristics of a vehicle depend directly on the shape-frictional force couple between car tyres and the surface. The value of this couple is a function of the road conditions, the type of tyres and weather conditions [3]. The driver, assisted by the traction control system, among others, has a significant influence on the optimal use of the tyre adhesion to the road surface.

The purpose of the research was to broaden the database of vehicle traction properties on a snowy road surface [4]. The behaviour of a vehicle equipped with winter tyres and non-skid snow chains has been studied during acceleration and deceleration of the car. This allowed a comparative analysis of traction characteristics of a car equipped with winter

\footnotetext{
* Corresponding author: michal.sledzinski@put.poznan.pl

Reviewers: Maciej Bodnicki, Marek Macko
} 
tyres and a car additionally equipped with anti-skid chains on a snow-covered surface. The influence of the traction control system (TCS) on car acceleration has also been studied.

\section{Methodology}

Road tests, conducted in two phases, consisted in accelerating the test car from a standing start to a speed of about $50-60 \mathrm{~km} / \mathrm{h}$ (phase one), and then in heavy braking to a complete stop (phase two). The tests have been conducted in four cycles: with chains on the front axle and without chains, with the traction control system turned on and turned off.

The Ford Mondeo car has been used for testing. Road conditions were characterised by the surface covered with a layer of beaten snow at a temperature of $-4^{0} \mathrm{C}$. In this research, accelerometers by Analog Devices fitted to the bodywork of the car have been used. During testing, acceleration on measurement sections has been recorded in the acceleration phase and deceleration phase $[5,6,7]$. Figure 1 shows the test car during the measurement and the wheel with the non-skid chain.
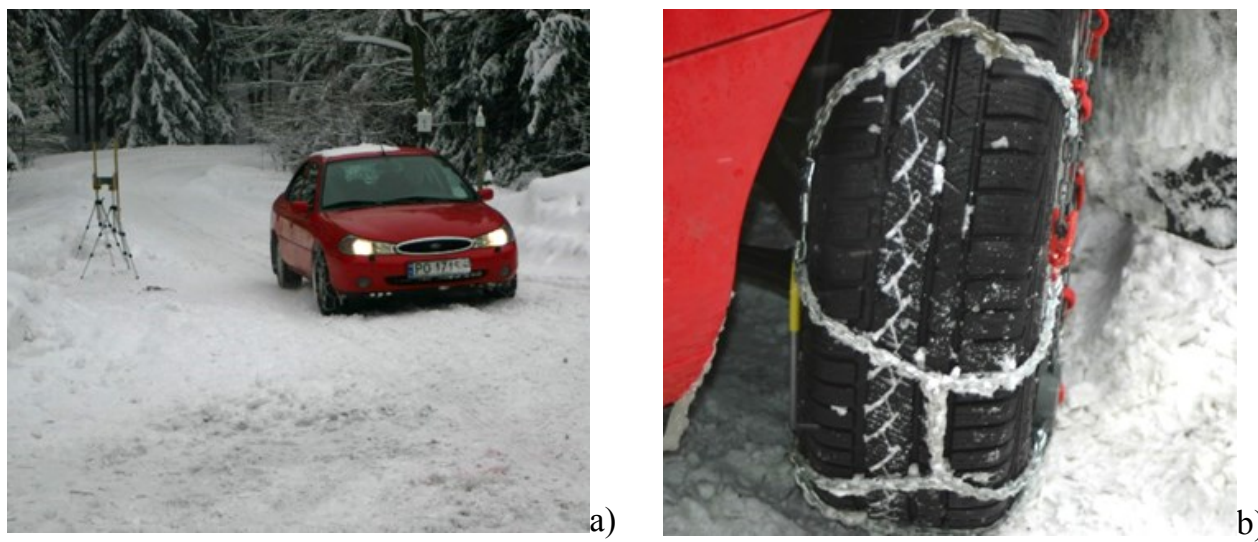

Fig. 1. The car during testing $-a$ ), the wheel with the non-skid chain $-b$ )

The recorded acceleration runs have been processed by means of a 6th order low-pass Butterworth filter, which made it possible to determine speed and distance variability in the function of time. Based on the ECE Regulation 13, mean fully developed deceleration (MFDD), has been determined according to [8]:

$$
M F D D=\frac{v_{b}^{2}-v_{e}^{2}}{S_{e}-S_{b}}\left[\frac{m}{s^{2}}\right]
$$

where:

$\mathrm{v}_{\max }$ - maximum speed of the car,

$\mathrm{v}_{\mathrm{b}}$ - speed equal to 0.8 of the maximum speed,

$\mathrm{v}_{\mathrm{e}}$ - speed equal to 0.1 of the maximum speed,

$\mathrm{S}_{\mathrm{b}}$ - distance travelled between speeds $\mathrm{v}_{\max }$ and $\mathrm{v}_{\mathrm{b}}$,

$\mathrm{Se}$ - distance travelled between speeds $\mathrm{v}_{\max }$ and $\mathrm{v}_{\mathrm{e}}$.

To determine the average acceleration of the car $\mathrm{a}_{\mathrm{avg}}$, the following formula has been used

$$
a_{a v g}=\frac{v_{b}^{2}-v_{e}^{2}}{S_{b}^{\prime}-S_{e}^{\prime}}\left[\frac{m}{s^{2}}\right]
$$


where:

$S_{b}{ }^{\prime}$ - distance travelled during acceleration to speed $\mathrm{v}_{\mathrm{b}}$,

$S_{e}{ }^{\prime}$ - distance travelled during acceleration to speed $\mathrm{v}_{\mathrm{e}}$.

\section{Experimental research results}

\subsection{Road testing results - the car with chains}

On the selected section of the road, 5 road tests with the TCS turned on and 6 tests with the TCS turned off have been conducted with a car equipped with winter tyres with chains. Table 1 shows the results of average acceleration during the acceleration phase and the braking phase.

Table 1. Results of the tests with chains

\begin{tabular}{|c|c|c|c|c|}
\hline Test No. & Max speed & $\begin{array}{c}\text { Acceleration } \\
\mathbf{a}_{\text {avg }}\end{array}$ & $\begin{array}{c}\text { Braking } \\
\text { MFDD }\end{array}$ & Use of TCS \\
\hline- & $\mathrm{m} / \mathrm{s}$ & $\mathrm{m} / \mathrm{s}^{2}$ & $\mathrm{~m} / \mathrm{s}^{2}$ & \\
\hline $\mathrm{CH} 1$ & 12.6 & 1.6 & -2.5 & - \\
\hline $\mathrm{CH} 2$ & 12.6 & 1.8 & -2.6 & - \\
\hline $\mathrm{CH} 3$ & 14.4 & 1.3 & -2.5 & - \\
\hline $\mathrm{CH} 4$ & 15.2 & 1.5 & -2.6 & - \\
\hline $\mathrm{CH} 5$ & 15.3 & 1.3 & -2.7 & - \\
\hline $\mathrm{Ch} 6$ & 15.9 & 1.2 & -2.2 & - \\
\hline $\mathrm{CH} 7$ & 16.6 & 1.3 & -2.0 & TCS \\
\hline $\mathrm{CH} 8$ & 16.4 & 1.2 & -2.8 & TCS \\
\hline $\mathrm{CH} 9$ & 15.3 & 1.2 & -2.7 & TCS \\
\hline $\mathrm{CH} 10$ & 16.7 & 1.3 & -2.7 & TCS \\
\hline $\mathrm{CH} 11$ & 16.9 & 1.3 & -2.5 & TCS \\
\hline
\end{tabular}

Designation: $\mathrm{CH} 1 \div \mathrm{CH} 11$ applies to the tests with chains, TCS - Traction Control System.

In the six conducted acceleration tests of the car with chains and TCS turned off, the obtained average acceleration values were in the 1.2 to $1.8 \mathrm{~m} / \mathrm{s}^{2}$ range. The average acceleration in this group is $1.44 \mathrm{~m} / \mathrm{s}^{2}$ with the standard deviation of $0.22 \mathrm{~m} / \mathrm{s}^{2}$. The range of acceleration variation in individual tests has been influenced by environmental factors and the driving style. In the test shown in Figure 2, marked as $\mathrm{CH} 2$, the highest average acceleration in the car acceleration phase has been obtained, ie. $1,8 \mathrm{~m} / \mathrm{s}^{2}$. 


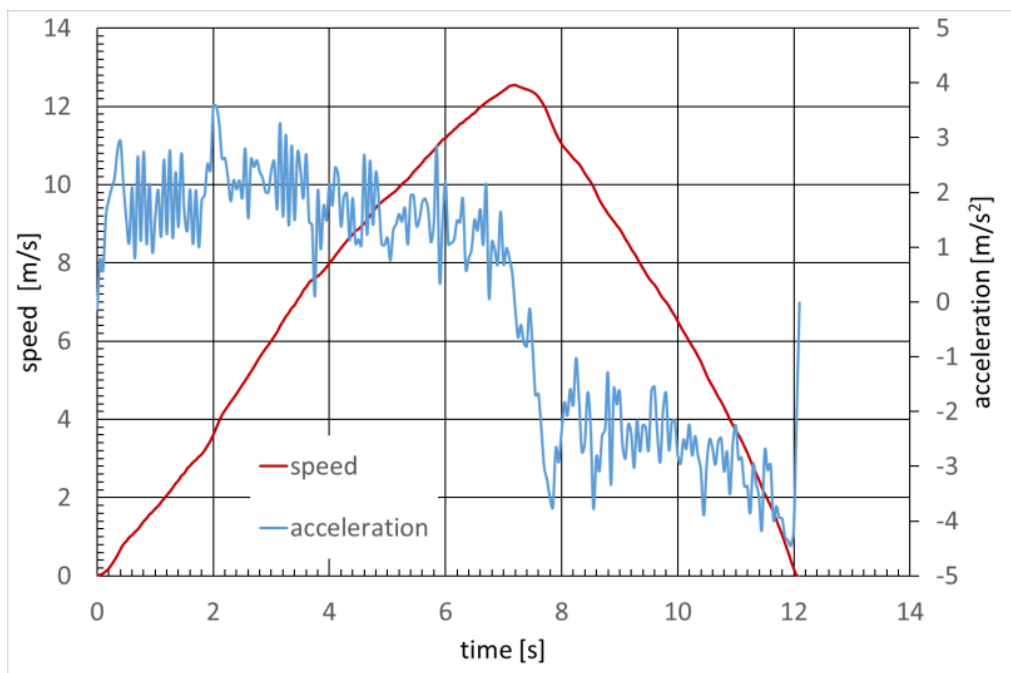

Fig. 2. The course of acceleration and speed of the car with chains and TCS turned off (CH2)

In the test $\mathrm{CH} 6$ the lowest acceleration value has been obtained. Figure 3 shows the differences between the speed runs in the function of time for tests $\mathrm{CH} 2$ and $\mathrm{CH} 6$. The graph shows that in the starting phase (for about 1 second), in both tests the vehicle accelerated with a similar intensity. In the test $\mathrm{CH} 6$, after that time, there was a reduction in acceleration, visible as a reduction of the car speed increase, which was probably related to a temporary increase in drive wheel slip.

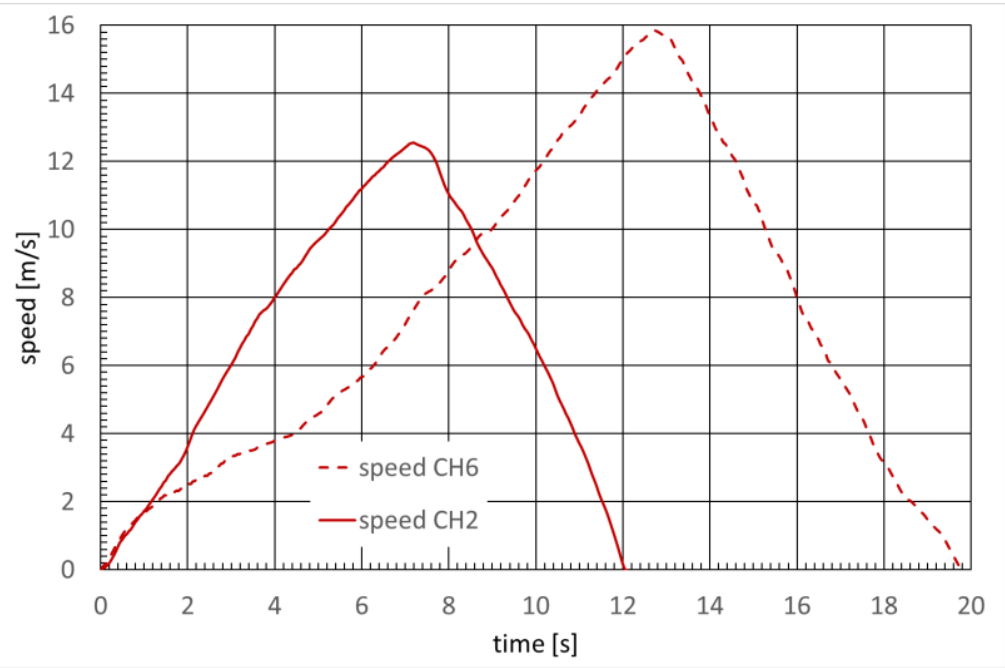

Fig. 3. Comparison of speed changes in tests $\mathrm{CH} 2$ and $\mathrm{CH} 6$ - the car with chains and TCS turned off

Figure 4 shows the run of the test $\mathrm{CH} 7$ with chains and TCS turned on. The diagram shows significantly smaller changes of acceleration in the test car acceleration phase relative to the tests with TCS turned off. In the five tests, the obtained average acceleration values were in the narrow range between $1.2 \div 1.3 \mathrm{~m} / \mathrm{s}^{2}$, which is clearly the effect of having the support system. The average acceleration in this group was $1.26 \mathrm{~m} / \mathrm{s}^{2}$ with the 
standard deviation of $0.05 \mathrm{~m} / \mathrm{s}^{2}$. Table 1 shows that maximum acceleration values have been lowered, which should be associated with the characteristics of the traction control system.

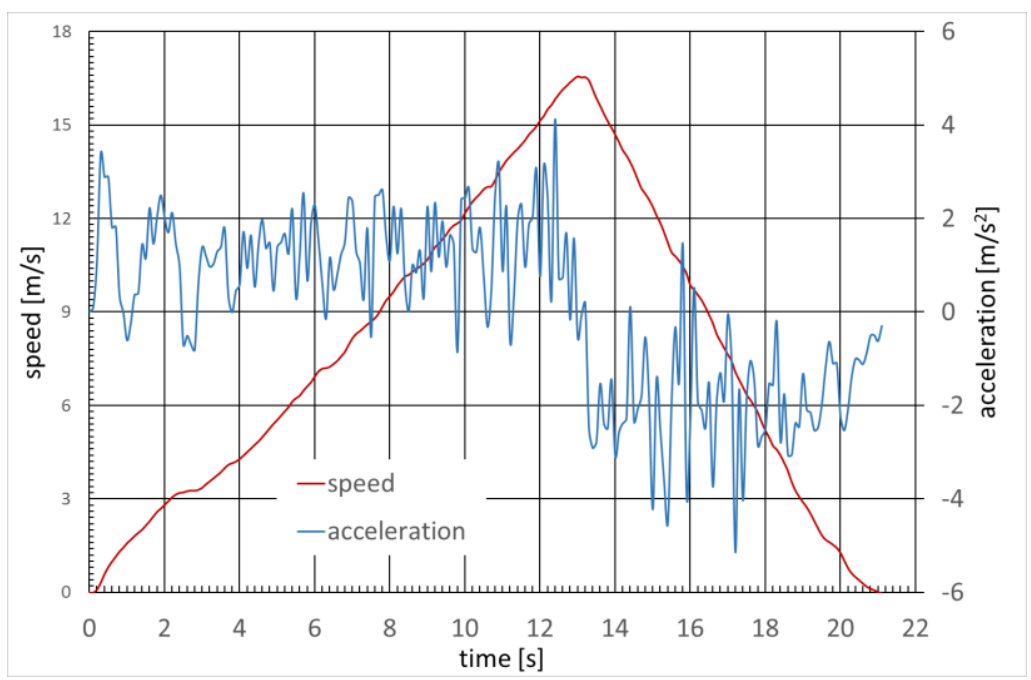

Fig. 4. The course of acceleration and speed of the car with chains and with TCS turned on (test $\mathrm{CH} 7)$

During the braking process of the car equipped with chains the obtained brake delays were in the $2.0 \div 2.8 \mathrm{~m} / \mathrm{s}^{2}$ range. The average brake delay in this group was $2.52 \mathrm{~m} / \mathrm{s}^{2}$ with the standard deviation of $0.22 \mathrm{~m} / \mathrm{s}^{2}$.

\subsection{Road testing results - the car without chains}

6 road tests have also been conducted with the car equipped with winter tyres, in two cycles (as in section 3.1), with TCS turned on and turned off. Table 2 shows the results of average accelerations during acceleration and braking.

In the six acceleration tests on the car with chains and TCS turned off, the obtained average acceleration values were in the $0.8 \div 1.1 \mathrm{~m} / \mathrm{s}^{2}$ range. The average acceleration in this group was $0.96 \mathrm{~m} / \mathrm{s}^{2}$ with the standard deviation of $0.10 \mathrm{~m} / \mathrm{s}^{2}$. The scale of variability in individual tests has been influenced by environmental factors [9] and the driving style. 
Table 2. Test results - the car without chains

\begin{tabular}{|c|c|c|c|c|}
\hline Test No & Max speed & $\begin{array}{c}\text { Acceleration } \\
\mathbf{a}_{\text {avg }}\end{array}$ & $\begin{array}{c}\text { Braking } \\
\text { MFDD }\end{array}$ & Use of TCS \\
\hline- & $\mathrm{m} / \mathrm{s}$ & $\mathrm{m} / \mathrm{s}^{2}$ & $\mathrm{~m} / \mathrm{s}^{2}$ & \\
\hline WCH1 & 14.9 & 0.9 & -2.2 & - \\
\hline WCH2 & 14.1 & 0.8 & -2.3 & - \\
\hline WCH3 & 14.6 & 0.9 & -2.8 & - \\
\hline WCH4 & 15.4 & 1.1 & -2.8 & - \\
\hline WCH5 & 15.3 & 1.0 & -3.0 & - \\
\hline WCH6 & 15.3 & 1.1 & -2.4 & - \\
\hline WCH7 & 15.9 & 1.1 & -2.8 & TCS \\
\hline WCH8 & 16.3 & 1.1 & -2.7 & TCS \\
\hline WCH9 & 15.9 & 1.1 & -2.7 & TCS \\
\hline WCH10 & 15.3 & 1.0 & -2.6 & TCS \\
\hline WCH1 & 15.7 & 1.1 & -2.6 & TCS \\
\hline WCH12 & 15.5 & 1.1 & -2.6 & TCS \\
\hline
\end{tabular}

Designation: $\mathrm{WCH} 1 \div \mathrm{WCH} 12$ applies to the tests without chains.

In the test shown in Figure 5, marked as WCH4, the highest average acceleration in the car acceleration phase has been obtained, ie. $1.1 \mathrm{~m} / \mathrm{s}^{2}$.

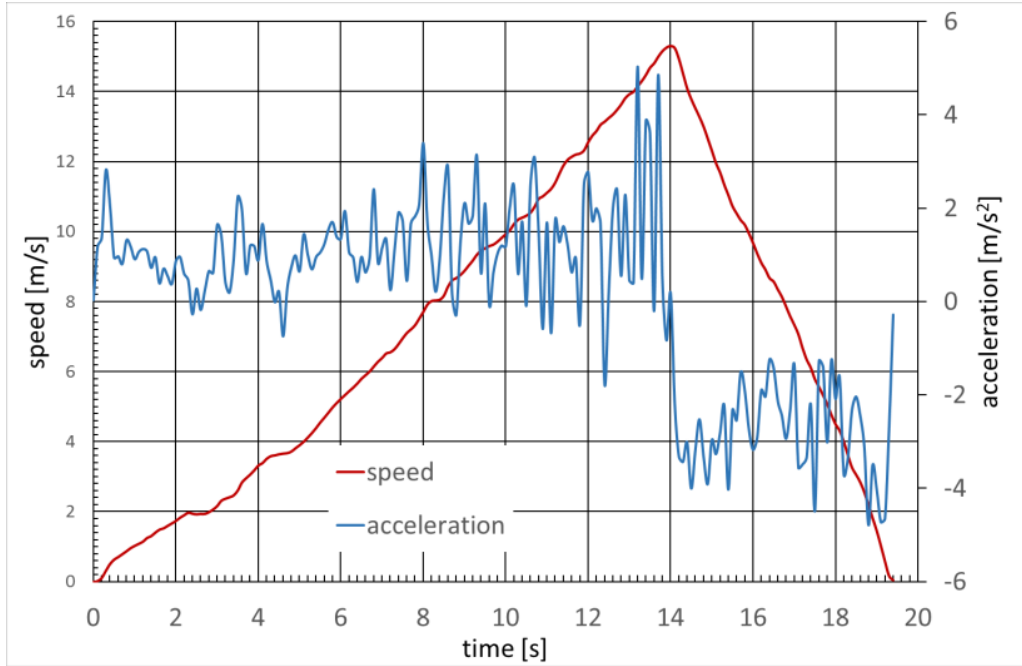

Fig. 5. The course of acceleration and speed of the car without chains and with TCS turned off (test WCH4)

Figure 6 shows the course of the test WCH8 without chains and with TCS turned on. In the six conducted tests the obtained average acceleration values were in the narrow range $1.0 \div 1.1 \mathrm{~m} / \mathrm{s}^{2}$. The average acceleration in this group was $1.10 \mathrm{~m} / \mathrm{s}^{2}$ with the standard deviation of $0.05 \mathrm{~m} / \mathrm{s}^{2}$. 


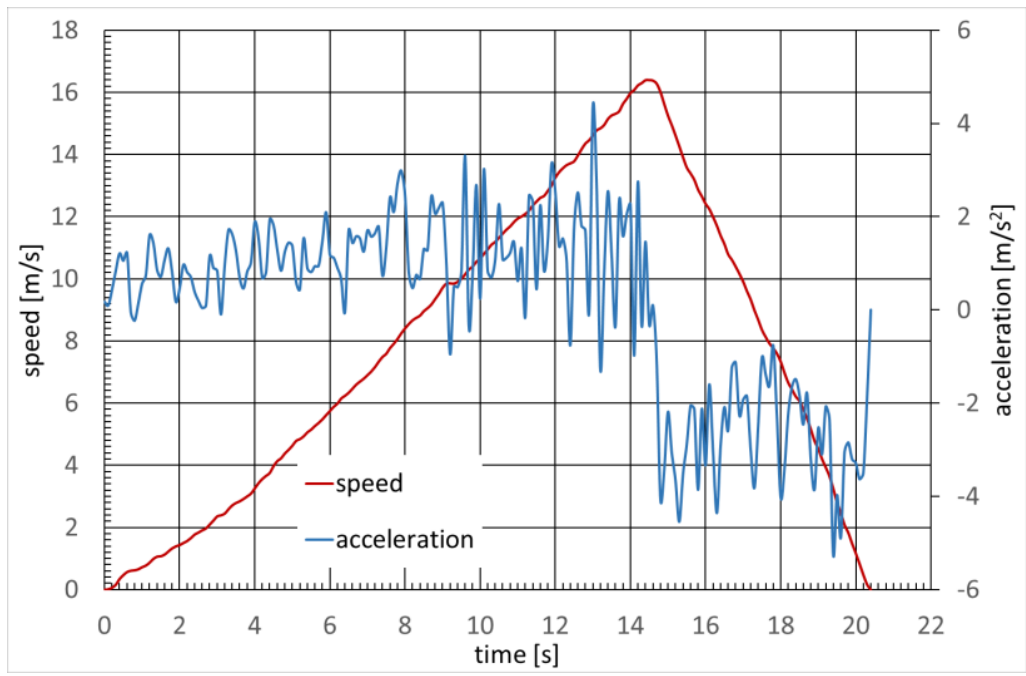

Fig. 6. The course of acceleration and speed of the car without chains and with TCS turned on (WCH8)

During the braking process of the car without chains the obtained brake delay was in the $2.2 \div 3.0 \mathrm{~m} / \mathrm{s}^{2}$ range. The average brake delay in this group is $2.64 \mathrm{~m} / \mathrm{s}^{2}$ with the standard deviation of $0.22 \mathrm{~m} / \mathrm{s}^{2}$.

\section{Conclusions}

The conducted road tests have showed that the use of chains increases the ability of a car to accelerate by approximately 50\% compared with driving without chains. Taking into account the relatively low values of the coefficient of adhesion on snowy and icy surfaces, it is a significant factor that increases traffic safety.

Based on the analysis of the research results, it has been found that the operation of the traction control system reduces the acceleration of a car equipped with non-skid chains only to a small extent. In case of movement of a car without chains, the TCS has favourable influence and increases acceleration values comparing to the car where TCS is turned off. Based on the research results, it has also been found that, contrary to expectations, during the braking phase the range of brake delay values for the car equipped with chains has been smaller than for one without chains. We conclude that this situation is related to the properties of ABS, which responds to local changes of adhesion of the wheels to the surface during shape-frictional contact of the chain with the surface. This issue requires further research.

The obtained results of road tests in snowy conditions expand the range of knowledge on traction properties and on the behaviour of a vehicle equipped with non-skid chains and on driving without chains, as well as contribute important insights about the impact of the traction control system. These data are important in expanding the databases used in the reconstruction of the road incidents and in project work. They can also be used in the practice of driver training and to assist their response process in actual emergency situations, which may contribute to an increase in the level of safety for vehicles in winter conditions. 


\section{References}

1. Praca zbiorowa, Wypadki drogowe. Vademecum biegłego sadowego. Wydanie II, Institute of Forensic Research Publishers Kraków (2010)

2. F. Navin, M. Macnabb, C. Nicolletti, Vehicle traction experiments on snow and ice. SAE Technical Paper Series, 960652, Detroit, Michigan, USA (1996)

3. Praca zbiorowa pod redakcją M. Dudziaka, Proces hamowania samochodu a bezpieczeństwo w ruchu drogowym. Wydawnictwo Instytutu Technologii Eksploatacji w Radomiu, Poznań-Radom (2002)

4. D.P. Martin, G.F. Schaefer, Tire-Road Friction in Winter Conditions for Accident Reconstruction. SAE Technical Paper Series, 960657, (1996)

5. A. Lewandowski, J. Warszczyński, M. Dudziak, K. J. Waluś, Analysis of the passenger car breaking process on an inclined road under winter conditions. Machine Modeling and Simulations, ed. Marian Dudziak et all., Rokosowo, Politechnika Poznańska, Katedra Podstaw Konstrukcji Maszyn, 147-152 (2012)

6. K. J. Waluś, Comparing the intensity of the acceleration of a passenger car eguipped with summer and winter tires in sub-zero road surface temperatures. Technolog $\mathbf{4}$, 262-264 (2013)

7. K. Kędziora, K. J. Waluś, Experimental and simulation research on car acceleration and braking on snow-covered roads. Activities of Transport Telematics, $13^{\text {th }}$ International Conference on Transport Systems Telematics, TST 2013 selected papers, Katowice-Ustroń, Poland, October 23-26, 2013, ed. Jerzy Mikulski, Springer Berlin Heidelberg, Communications in Computer and Information Science 395, 433-440 (2013)

8. Regulation No. 13 (UNECE), Uniform provisions concerning the approval of vehicles of categories $M, N$ and $O$ with regard to braking.

9. M. Dudziak, A. Lewandowski, J. Warszczyński, M. Anioła, K., Kędziora, K. J. Waluś, Wplyw cech nawierzchni $i$ otoczenia na parametry ruchu pojazdu $w$ warunkach zimowych (badania pilotażowe). Materiały XX Francusko-Polskiego Seminarium Mechaniki VII Konferencji Międzynarodowej „Tarcie 2012”, Warszawa, Politechnika Warszawska, 24-29 (2012) 